Review

\title{
Pancreatic beta-cells: From generation to regeneration
}

\author{
Patrick Collombat ${ }^{\mathrm{a}, \mathrm{b}}, \mathrm{Xiaobo}_{\mathrm{Xu}}^{\mathrm{c}, \mathrm{d}, \mathrm{e}}$, Harry Heimberg ${ }^{\mathrm{c}, \mathrm{d}, \mathrm{e}, *}$, Ahmed Mansouri ${ }^{\mathrm{c}, \mathrm{f}, \mathrm{g}, * *}$ \\ a Inserm U636, Diabetes Genetics Team, FR-06108, Nice, France \\ b Université de Nice Sophia-Antipolis, FR-06108, Nice, France \\ c Beta-cell Biology Consortium, 2213 Garland Avenue, 9465 MRB IV, Nashville, TN 37323-0494, USA \\ d JDRF Center for Beta-cell Therapy in Diabetes, Laarbeeklaan 103, B-1090 Brussels, Belgium \\ e Diabetes Research Center, Vrije Universiteit Brussel, Laarbeeklaan 103, B-1090 Brussels, Belgium \\ ${ }^{\mathrm{f}}$ Max-Planck Institute for Biophysical Chemistry, Department of Molecular Cell Biology, Am Fassberg, D-37077 Göttingen, Germany \\ ${ }^{g}$ Department of Clinical Neurophysiology, University of Göttingen, Robert-Koch Strasse 40, D-37075 Göttingen, Germany
}

\section{A R T I C L E I N F O}

\section{Article history:}

Available online 3 August 2010

\section{Keywords:}

Pancreas

Stem cells

Regeneration

Mouse

Diabetes

\section{Contents}

1.

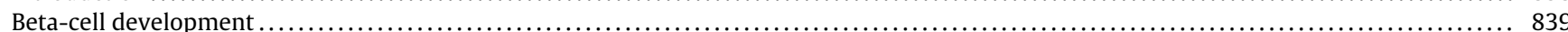

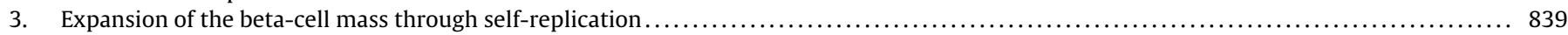

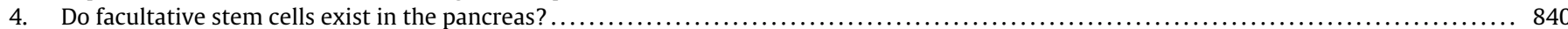

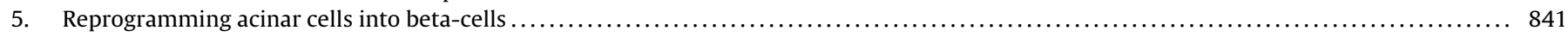

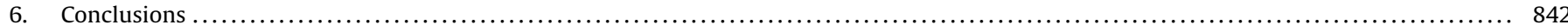

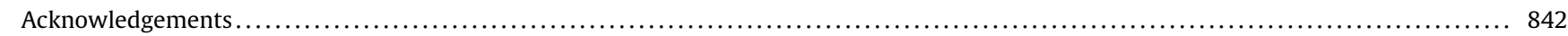

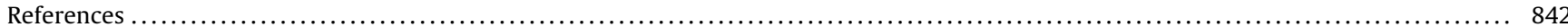

\section{Introduction}

Although insulin supplementation allows a reasonable control of blood sugar levels, diabetic patients still suffer from long-term side effects of blood glucose variations, too often resulting in severe alterations of various organ functions. Transplantation of islets

\footnotetext{
* Corresponding author.

** Corresponding author at: Max-Planck Institute for Biophysical Chemistry, Department of Molecular Cell Biology, Am Fassberg, D-37077 Göttingen, Germany. Tel.: +49 5512011709; fax: +495512011504.

E-mail addresses: Harry.Heimberg@vub.ac.be (H. Heimberg), amansou@gwdg.de (A. Mansouri).
}

isolated from the pancreases of organ donors alleviates insulindependence in type 1 diabetes patients, providing strong support to stem cell-based therapy. It is obvious that, due to the islet shortage to suffice the need for transplantation, alternative cell sources have to be explored. At first glance, human embryonic stem (hES) cells and induced pluripotent stem cells (iPS) potentially may represent an unlimited source for generating beta-cells in vitro. However, although several straightforward protocols were established, including procedures using chemical compounds, both the efficiency of in vitro programming and the function of h-ES-derived beta-cells remain unsatisfactory. Besides, safety concerns due to inherent risks of teratoma formation originating from residual stem cells remain a major hurdle [1-3]. 
It is now accepted that in various experimental animal models of injury to the (endocrine) pancreas, such as partial pancreatectomy (PPX), partial duct ligation (PDL), and chemically- or geneticallyinduced beta-cell destruction, [4-10], islet cells actively regenerate. It is therefore of fundamental interest to consider the molecular mechanisms that control such regenerative programs to putatively open new avenues for an improved treatment of diabetes. The expansion of the beta-cell mass during early postnatal life, pregnancy, as well as in the pancreas of animal models for which beta-cells were genetically ablated, has been mainly attributed to beta-cell proliferation $[7,11,12]$. Despite these findings, it was demonstrated that beta-cells may also arise from alternative cell subtypes, such as duct-lining or acinar cells [13], as observed during embryonic development. Indeed, several studies in various animal and transgenic models support a process of duct-lining cellderived beta-cell neogenesis [4,14-22]. However, as we will discuss thereafter, while replication of preexisting beta-cells has been established as a major component of the expansion of the beta-cell mass in normal and injured pancreas, the existence of duct-derived progenitor cells is still controversially discussed [23-25]. Finally, intra-islet precursor cells promoting beta-cell neogenesis have been also suggested [26-28].

\section{Beta-cell development}

The first obvious morphological signs of pancreas development appear at approximately 8.5 days post-coitum, as two protusions at the dorsal and ventral portion of the foregut/midgut junction [29-32]. The specification of this endodermal region towards a pancreatic fate is achieved through the concerted interplay of different signaling pathways emanating from the adjacent mesoderm [32-34]. During subsequent pancreas histogenesis, both the dorsal and the ventral buds develop under the control of distinct signaling machineries, their growth and branching being regulated by the surrounding mesenchyme [32,35-37]. In the mouse, the ventral pancreatic bud rotates and eventually fuses with its dorsal counterpart between E17 and E18 of embryonic development [32].

During pancreas morphogenesis, the first hormone-expressing cells that are detected contain glucagon and appear at E9.5, some of which initiating insulin expression a day later [29,38]. However, these few early scattered cells that produce both insulin and glucagon will not contribute to the mature endocrine pancreas [39]. Endocrine and exocrine cell proliferation peaks at the so-called secondary transition starting at about E13.5 [29]. Multipotent progenitor cells located at the distal tip of the growing epithelium are characterized by the expression of Ptf1a, c-myc, and carboxypeptidase a1 (cpa1) [40]. Lineage tracing experiments demonstrated that cpa1-positive cells delaminate from the epithelium to generate all pancreatic cell types, including Ngn3-marked cells that will adopt an endocrine cell fate. Accordingly, in the absence of Ngn3, endocrine cells fail to develop [41]. It is worth noticing that Ngn3-labeled endocrine progenitors are subjected to a window of competence for the generation of the different endocrine hormone-producing cell subtypes [42]. At about E14.5, cpa1-labeled progenitors are restricted towards the acinar lineage [40]. Concurrently, a significant number of maturing insulinor glucagon-labeled endocrine and amylase-labeled acinar cells accumulate. At E15.5, the first somatostatin-expressing delta-cells appear. Lastly, shortly before birth, PP-labeled cells emerge and aggregation of endocrine cells to form mature islets of Langerhans is initiated [29].

The use of gain- and loss-of-function mutant mice as a tool to study gene function has allowed to gain further insights into the crucial role exerted by transcription factors in the processes underlying endocrine cell specification (excellently reviewed in
[30-32,36,43]). However, gaining further insights into the molecular mechanisms controlling normal beta-cell development, as well as their replenishment in animal models of beta-cell injury, is of fundamental interest for the generation of insulin-producing cells from progenitor or embryonic stem cells.

\section{Expansion of the beta-cell mass through self-replication}

Glucose-mediated insulin secretion is required for the proper control of glucose homeostasis. Interestingly, during pregnancy [11] or in obese individuals [44], a beta-cell mass expansion was outlined to compensate for the increased needs. Although several molecular mechanisms promoting adaptation of the functional beta-cell mass are under discussion, self-duplication of preexisting beta-cells unquestionably represent an important process to increase islet size. Accordingly, Cre recombinase-mediated lineage tracing analyses provided compelling evidences for beta-cell replication as the main source of beta-cell neogenesis under normal physiological conditions, but also following 70\% PPX [45]. Another in vivo pulse-chase study, supplemented by a clonal analysis of dividing beta-cells, supported a model where insulin-expressing cells equally participate to the replication-mediated expansion of the beta-cell mass [12]. In addition, using a novel DNA analogbased lineage tracing approach, it was found that only beta-cells contribute to the beta-cell regeneration occurring under normal physiological conditions, following 50\% PPX or treatment with the GLP-1 agonist Exendin-4, and during pregnancy, underscoring the importance of replication to sustain the beta-cell turn-over [46]. These findings were confirmed by studies in transgenic mice with beta-cell depletion induced by tetracycline-controlled diphtheria toxin expression or by c-myc activated overexpression leading to beta-cell apoptosis [7,47].

In rodents, beta-cell replication appears to follow an agedependent process for which the beta-cell mass expansion observed next to pancreas injury seems limited to young animals $[48,49]$. Accordingly, the proliferation rate of insulin-producing cells was found extremely reduced in 1-year old mice [49], with a Ki67 proliferation index significantly decreased in islets of 94week old animals as compared to their 20-week old counterparts [50]. Furthermore, a clear decline in islet proliferation capability upon 90\% PPX was also associated with age in rats [51].

Beta-cell replication obviously requires the activity of cell cycle regulators (for review see [52-54]). Accordingly, cyclin D2-deficient mice exhibit smaller islets, a dramatically reduced beta-cell mass, and compromised beta-cell proliferation capabilities $[55,56]$. While the lack of Cdk4 activity results in diabetes, the expression of a constitutively active form of Cdk4 is accompanied by beta-cell hyperplasia [57-59]. Moreover, virus-mediated overexpression of Cdk4 in human islets also induces beta-cell proliferation [52,58,60]. Similarly, the adenovirus-mediated ectopic expression of E2F1, together with protein kinase B (Akt), in primary beta-cells, results in an increase in the absolute cell number provoked by an induction of proliferation and a concomitant inhibition of cell death [61]. On the other hand, the in vivo conditional overexpression of E2F1 in beta-cells stimulates their proliferation, but not sufficiently enough to increase the beta-cell mass. However, increased insulin contents and glucose-mediated insulin release were noticed and associated to protection against STZ (streptozotocin)-induced diabetes [61].

The diminished proliferation ability in aging mice was recently correlated with an increased expression of the cell cycle inhibitor p16 ${ }^{\text {INK4a }}$ in older animals [62-64]. Accordingly, the loss of $\mathrm{p} 16^{\text {INK4a }}$ activity in mutant mice results in improved regeneration capabilities in islets of older animals following chemical ablation of beta-cells using streptozotocin (STZ), while the overexpression of 
p16 ${ }^{\text {INK4a }}$ is accompanied by diminished islet proliferation [62]. Moreover, the propensity of beta-cells to multiply in younger animals strongly correlates with the expression levels of Bmi1 and Ezh2, two polycomb proteins that control the Ink4a/Arf locus through modulation of histone modifications [65,66]. Hence, Bmi1-deficient young mice display increased expression of $\mathrm{p} 16^{\mathrm{INK} 4 \mathrm{a}}$, and thereby lose their capacity to expand their beta-cell mass in response to exendin-4 [63]. Similarly, in the absence of Ezh2, insulin-producing beta-cells exhibit reduced proliferation rates and mutant mice suffer from mild diabetes [66]. Interestingly, MLL, a member of trithorax TrxG protein family, was found associated to the activation of the Ink4a/Arf locus [65]. Menin, a factor encoded by the men 1 locus, recruits MLL to the p27kip1 and p18Ink4c promoters [67] and thereby modulates pancreatic islet growth by inducing histone methylation and activating the transcription of cell cycle inhibitors [68]. These findings underscore the role of epigenetic control of the beta-cell mass expansion during life span. Finally, it is worth noticing that other signaling pathways and factors, such as STAT5, growth hormones, prolactin and FoxM1 also play a role in beta-cell proliferation during pregnancy $[11,30,65]$.

\section{Do facultative stem cells exist in the pancreas?}

Recent studies indicate that adult pancreatic cells are more "plastic" than hitherto assumed, and provide evidence for islet neogenesis in several animal models. One attractive hypothesis favors injury-induced activation of facultative stem/progenitor cells to expand the beta-cell mass $[4,14,69,70]$. Differentiation of facultative stem/progenitor cells might involve recapitulation of the program that controls the embryogenesis of the endocrine pancreas, including re-expression of the proendocrine factor Ngn3. As a common denominator to these reports, the ductal compartment seemingly represents the site where stem/progenitor cells at least transiently reside $[4,16-22]$. Robust injury using partial pancreatic duct ligation created the appropriate microenvironment to unambiguously demonstrate the existence of multipotent endocrine progenitors in the adult mouse pancreas [19]. In this model, at least part of the embryonic endocrine program is reinitiated leading to reactivation of $\mathrm{Ngn} 3$ in a subset of $\mathrm{Pdx} 1^{+}$cells lining the duct. Ngn3positive cells isolated from adult duct-ligated pancreata gave rise to the four main endocrine cell subtypes when implanted in pancreata of embryonic mice that were null mutant for Ngn3 and thus incapable of producing endogenous endocrine cells. Remarkably, the Ngn $3^{-1-}$ embryonic pancreata explants engrafted with adult $\mathrm{Ngn}^{+}$cells were glucose responsive and the newly formed betacells intensely proliferated [19]. Lineage tracing experiments using the human carbon anhydrase II (CAII) promoter to drive the expression of cre recombinase and follow the progeny of pancreatic duct cells following birth or partial duct ligation showed that CAII cells can give rise to both endocrine and exocrine cells [20].

In yet another model, conditional expression of Pax4 allowed the transcription factor to be ectopically present in alpha-cells and initiate their conversion into functional beta-cells [21]. The ensuing glucagon shortage induced compensatory neogenesis of glucagon-producing cells. Along the same line of evidence, deficiency/alterations in glucagon signaling in glucagon receptor knockout or prohormone convertase-deficient mice were previously found to also trigger alpha-cell hyperplasia [71,72]. Upon Pax4 misexpression, alpha-cells consequently adopted a beta-cell phenotype leading to oversized islets mainly comprised of insulinproducing cells [21]. Importantly, in transgenic mice misexpressing Pax4 in alpha-cells, a progressive normalization of the glycemia was observed in mice that underwent chemically-induced diabetes. The regenerated alpha-cells noted in Pax4 transgenic mice were found to originate from the reactivation of $\mathrm{Ngn} 3$, but not Pdx1, in the ductal lining. Moreover, knockdown experiments using Ngn3specific interfering RNA demonstrated the requirement of Ngn3 re-expression for endocrine cell neogenesis in Pax4 transgenic mice [21].

Recently, mice expressing a constitutively active form of Cdk4 $\left(\mathrm{Cdk} 4^{\mathrm{R} 24 \mathrm{C}}\right.$ ) displaying beta-cell hyperplasia (see also above), were found to exhibit increased proliferation rates of beta-cells, but also of ductal cells, following 60\% pancreatectomy [22]. Duct cells in injured pancreas of both $\mathrm{Cdk} 4^{\mathrm{wt}}$ and $\mathrm{Cdk} 4^{\mathrm{R} 24 \mathrm{C}}$ mice contained $\mathrm{Pdx} 1^{+}$cells and were able to express insulin. In this study, however, no $\mathrm{Ngn}^{+}$cells were observed prior to or following pancreatectomy [22]. In contrast, wild type mice and FoxM1-deficient animals exhibit Ngn3 re-expression in the duct epithelium after $60 \%$ pancreatectomy [73]. This discrepancy may be due to the technical difficulties encountered using immunohistochemical detection of Ngn3 expression in the adult tissue. In the adult injured pancreas, the duct epithelium often contains insulin-, glucagon- or Glut-2-expressing cells, suggesting islet neogenesis [15,74-76]. Finally, adult transgenic mice expressing the human diphtheria toxin receptor under the control of the insulin promoter to induce global beta-cell ablation by diphtheria toxin treatment were also found to undergo beta-cell regeneration through spontaneous conversion of alpha-cells [8].

Together these findings provide evidence that, besides beta-cell replication, additional mechanisms of islet regeneration operate in the adult pancreas, some involving facultative stem cells. The mechanism underlying such beta-cell neogenesis appears to depend on the extent and/or the method of beta-cell injury. The ductal origin of endocrine cell formation in adult injured pancreas still remains controversial. In contrast to the clear contribution of carbonic anhydrase II-positive cells to endocrine and exocrine cell neogenesis following birth and PDL [20], such ductal origin was not noticed for Hnf1b-marked cells following PDL- or alloxan/EGF/gastrin-induced injuries $[23,25]$. Furthermore, no contribution of acinar and of duct cells to endocrine cell genesis in the early postnatal period was observed by conditional lineage tracing of $\mathrm{Muc}^{+}$cells [24]. It remains to be determined whether, in the injured pancreas, Muc1-labeled cells are involved in beta-cell regeneration.

It needs to be mentioned that cre recombinase-mediated lineage tracing strongly depends on the efficiency of recombination and that never all duct cells are labeled, increasing the chance to overlook rare stem cells residing in the duct epithelium or acinar cell compartment (see also [77]). $\mathrm{Ngn}^{+}$cells were clearly detected in the duct of mice subjected to PDL, or with ectopic Pax4 expression in alpha-cells $[19,21]$.

Besides the ductal lining, intra-islet precursor cells as well as acinar cells were suggested to contribute to beta-cell neogenesis $[18,26,28,70,78,79]$. In mice treated with STZ and kept normoglycemic using exogenous insulin (STZ/IN), as well as in aging animals, two seemingly distinct beta-cell precursors were detected in islets [70]. These cells were characterized by the expression of Glut-2 and Pdx1/somatostatin, respectively. In RIPcreER and Z/AP reporter mice [45] that label insulin ${ }^{+}$cells by placental alkaline phosphatase (PLAP) and allow identification of putative precursor cells, the islets of aging and STZ/IN-treated mice contained beta-cell precursors expressing either Pdx1 or Mafb [28]. These findings contrast with the beta-cell replication described earlier [45], and were attributed to differences in immunhistochemical techniques [28]. However, the source of these putative precursor cells remains unclear and, as the authors pointed out, they may also have a ductal origin. Interestingly, Glut-2-positive cells were also detected in the PANIC-ATTAC mouse model characterized by beta-cell injury provoked by the activation of caspase 8-mediated apoptosis, as well as in the pancreatic duct of PDL-treated rats $[15,75]$. 
It is worth noticing that the $\mathrm{Mafb}^{+}$cells, probably representing alpha-cells, detected in the islets of STZ/IN-treated or aging mice [28], are reminiscent of glucagon ${ }^{+}$cells that spontaneously convert to beta-cells, following diphtheria toxin-mediated beta-cell depletion [8]. In both studies mice were treated with insulin to counter hyperglycemia and allow survival $[8,28]$. It is conceivable that the Mafb- or glucagon-marked cells contributing to beta-cell replenishment in these mice may derive from the duct epithelium, not excluding that intra-islet precursor cells may exist as well. Duct-derived endocrine cell neogenesis requires the reactivation of Ngn3 in the duct epithelium following pancreatic duct ligation or forced expression of Pax4 in alpha-cells [19,21]. Hence, ductderived progenitors that differentiate into hormone producing cells may migrate in order to expand that beta-cell pool or, alternatively, form new islets adjacent to the duct epithelium.

\section{Reprogramming acinar cells into beta-cells}

As the most abundant cell type in pancreas, acinar cells are considered as a rich supply for generating beta-cells [80]. Culturing the acinar cancer cell line AR42J in the presence of betacellulin, activin or glucagon-like peptide, was found to induce insulin or glucagon production [81-83]. Dexamethasone treatment of ductligated rat pancreas provoked acino-ductal transdifferentiation and revealed an intermediate cell type coexpressing both acinar and duct markers [84]. The currently most successful approach consists in supplementing rat acinar cell culture with the cytokines epidermal growth factor (EGF) and leukemia inhibitory factor (LIF) to generate functional beta-cells that normalized hyperglycemia in immune-incompetent diabetic mice [85]. This transdifferentiation process was found to pass through an intermediary cell type that expresses both duct- and beta-cell markers [85], such results being confirmed by non-genetic lineage tracing [86]. Acinar- to betacell reprogramming uses Notch signaling as gatekeeper [86] and requires both Ngn3 expression and signaling through the JAK/STAT pathway [87]. The notion of acinar- to beta-cell differentiation was further supported by genetic lineage tracing in suspension cultures of adult pancreatic exocrine cells isolated from transgenic mice expressing the ROSA26-eCFP, infected with recombinant adenoviruses expressing Cre under the control of the promoter of either amylase- 2 or elastase- 1 in cell cultures supplemented with EGF and nicotinamide [88]. Furthermore, in vitro culture of pancreatic explants isolated from transgenic mice expressing TGF-alpha under the control of the metallothionein promoter, revealed that acinar-to-duct transdifferentiation occurs through a dedifferentiated nestin-positive intermediate, in an EGFR-dependent manner [89]. It has been speculated that EGF activation in pancreatic exocrine cell cultures could be triggered by cell dissociation and that exogenous EGF might enhance cell survival [88].

In addition, transgenic mice expressing IFN-gamma under the control of the insulin promoter countered STZ-mediated beta-cell depletion through the budding of newly formed islets from ducts, with acinar cells as putative precursors [90]. In contrast, during regeneration of the mouse exocrine pancreas after caeruleininduced pancreatitis, acinar cell dedifferentiation was observed without further redifferentiation into duct cells [91]. Replenishment of the exocrine tissue in caerulein-mediated pancreatitis depended on the Notch signaling pathway and was mediated by repression of beta-catenin signaling pathway [92]. In transgenic mice expressing the tamoxifen-inducible Cre recombinase (CreERT2) under the control of the acinar-specific promoter elastase I, and crossed with Rosa26LacZ mice, lineage tracing was performed in three models with pancreas injury, including PPX, PDL and caerulein-induced pancreatitis, but no evidence for the contribution of acinar cells to islet neogenesis was found [93]. Following
PPX, self-replication of preexisting acinar cells was the predominant mechanism involved in regeneration of the newly formed acinar tissue [94]. This indicates that the capacity of adult acinar cells to transdifferentiate into endocrine cells in vivo is still a matter of debate und that more challenging studies are needed. On the other hand, the forced co-expression of Pdx1, Ngn3 and Mafa in acinar cells promoted the formation of insulin-producing betacells in vivo by direct conversion rather than dedifferentiation [95]. The reprogramming of acinar cells by the forced expression of transcription factors suggests that the transdifferentiation of acinar to endocrine cells is under the control of a repressive mechanism, like Notch signaling, in the normal pancreas. Accordingly, inhibition of Notch1 signaling results in a more efficient acinar- to beta-cell conversion [86].

Finally, the centroacinar and terminal duct cells of the pancreas are not well defined and their molecular characteristics poorly established $[96,97]$. Only few studies have suggested that these cells have the capacity to actively proliferate in different injury models, including PPX, or treatment with caerulein or STZ $[18,98,99]$. However, it is not clear whether the centroacinar and terminal duct (CA/TD) cells consist of distinct cell types or are functionally equivalent. Recently, these cells were characterized by immunhistochemistry and were found to display high levels of ALDH1 enzymatic activity [100] enabling their isolation by FACS. Isolated CA/TD cells are able to differentiate into endocrine and exocrine cell types in vitro. Following caerulein administration to

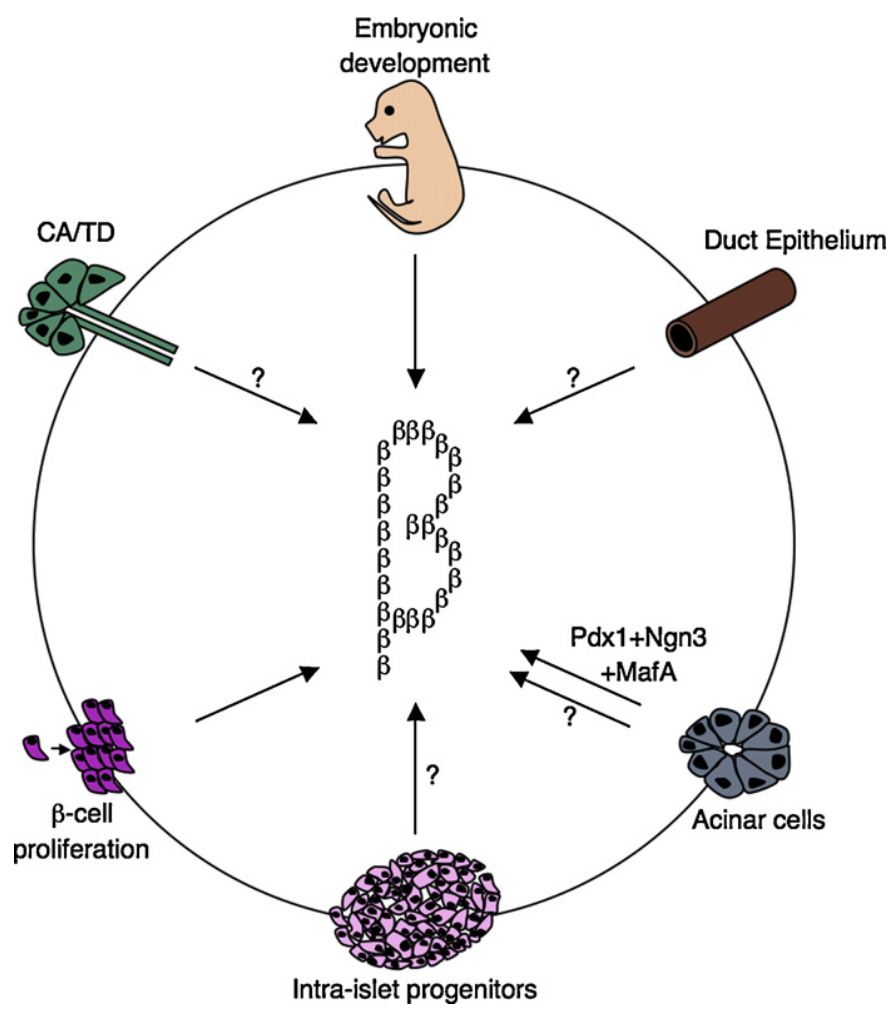

Fig. 1. Beta-cell development and regeneration. Schematics representing various roadmaps leading to the generation of functional insulin-producing cells. During embryonic development, beta-cells are generated from $\mathrm{Ngn}^{+}$progenitors. Moreover, beta-cells have the capacity to undergo self-replication to expand the beta-cell mass. This occurs during development, pregnancy, and following injury. Findings from several independent studies, using various pancreas injury models, are consistent with the idea that stem/progenitor cells do exist in the adult pancreas. Several sources of facultative stem/progenitor cells were suggested and are depicted: duct epithelium, acinar cells, centroacinar (CA)/terminal duct (TD), and intra-islet progenitors. Glucagon ${ }^{+}, \mathrm{Pdx}^{+}$, and $\mathrm{Ngn}^{+}$were often found in the duct lining, suggesting that this may be a site where stem/progenitor cells at least transiently reside. 
induce pancreatitis, ALDH1 ${ }^{+}$CA/TD cells were found expanded, as compared to controls, suggesting that CA/TD cells possess progenitor cell characteristics [100]. Along the same line, lineage tracing of Bmi $1^{+}$cells identified a self-renewing pancreatic acinar cell subpopulation capable of maintaining pancreatic organ homeostasis [101]. Further studies are needed to examine whether CA/TD cells are able to contribute to the endocrine cell compartment, as previously suggested [18,99] (see Fig. 1 ).

\section{Conclusions}

Beta-cell proliferation clearly appears as the fundamental mechanism involved for beta-cell turn-over. The induction of beta-cells in vitro to generate sufficient numbers of cells for transplantation would be an interesting alternative if at least the expanded betacell mass would remain glucose responsive. A similar approach in vivo should carefully take the risk of tumor formation, such as insulinomas, into account.

Islet transplantation demonstrated that stem cell-based therapy could represent a realistic option for the treatment of diabetes. Hence, the current islet shortage may be compensated in the future by the generation of insulin-producing beta-cells from pancreatic non-beta-cells, beta-cell progenitors or embryonic stem cells. Besides embryonic stem cells, it is now well accepted that the injured adult pancreas has the capacity to regenerate new betacells: several independent studies in various animal models of beta-cell injury provided strong evidences for the existence of facultative stem cells that are able to give rise to functional beta-cells. The source of such cells still is subject of controversial discussion. A molecular analysis of the current models is required to identify the factors implicated in the activation of such cells. Gaining further insights into the molecular mechanisms underlying regeneration processes may disclose the different cell sources that are implicated in endocrine cell neogenesis. It should be outlined that, depending on the type of pancreatic injury, different progenitor cells might be activated. In this context, it is of high interest to define how the application of insulin to streptozotocin-treated mice may activate the regeneration of significantly more beta-cells, as compared to streptozotocin-treated mice that remain hyperglycemic $[28,70]$. One possible explanation is that high glucose levels in hyperglycemic animals may perturb or inhibit islet neogenesis and beta-cell regeneration.

Nevertheless, the hunting for tools that activate stem cells in vivo, or induce the transdifferentiation of non-beta hormoneproducing cells, such as alpha-cells, into functional beta-cells, is now open. Future efforts should focus on the identification of markers for facultative stem cells in the injured pancreas and examine whether such molecules also do exist in the human pancreas.

\section{Acknowledgements}

Due to space constrains we apologize to many colleagues in the field whose work we could not cite. The authors are supported by the Max-Planck Society, the Bundesministerium für Bildung und Forschung (BMBF 01KU0906), the Dr. H. Storz and Alte Leipziger foundation (AM), the Juvenile Diabetes Research Foundation (26-2008-639), the INSERM AVENIR program, the INSERM, the Fondation pour la Recherche Médicale (DRC20091217179), the Agence Nationale de la Recherche (2009 GENO 105 01), the Schlumberger Foundation (PC), the NIH Beta Cell Biology Consortium (DK05U19DK072495 - AM, PC, HH), the Research Council Vrije Universiteit Brussel, JDRF (XX and HH), the European Federation for the Study of Diabetes, the National Fund for Scientific Research-Flanders, and the European Union (HH).

\section{References}

[1] Borowiak M, Melton DA. How to make beta cells? Curr Opin Cell Biol 2009;21:727-32.

[2] Ricordi C, Edlund H. Toward a renewable source of pancreatic beta-cells. Nat Biotechnol 2008;26:397-8.

[3] McKnight KD, Wang P, Kim SK. Deconstructing pancreas development to reconstruct human islets from pluripotent stem cells. Cell Stem Cell 2010;6:300-8

[4] Bonner-Weir S, Sharma A. Pancreatic stem cells. J Pathol 2002;197:519-26.

[5] Mordes JP, Rossini AA. Animal models of diabetes. Am J Med 1981;70:353-60.

[6] Bouwens L, Kloppel G. Islet cell neogenesis in the pancreas. Virchows Arch 1996;427:553-60.

[7] Nir T, Melton DA, Dor Y. Recovery from diabetes in mice by beta cell regeneration. J Clin Invest 2007;117:2553-61.

[8] Thorel F, Nepote V, Avril I, Kohno K, Desgraz R, Chera S, et al. Conversion of adult pancreatic alpha-cells to beta-cells after extreme beta-cell loss. Nature 2010;464:1149-54.

[9] Xu X, D’Hoker J, De Leu N, Xiao X, Heremans Y, Van De Casteele M, et al. Islet regeneration. Stem cell therapy for diabetes. Tel Aviv: Humana Press; 2010. p. $105-22$.

[10] Granger A, Kushner JA. Cellular origins of beta-cell regeneration: a legacy view of historical controversies. J Intern Med 2009;266:325-38.

[11] Rieck S, Kaestner KH. Expansion of beta-cell mass in response to pregnancy. Trends Endocrinol Metab 2010;21:151-8.

[12] Brennand K, Huangfu D, Melton D. All beta cells contribute equally to islet growth and maintenance. PLoS Biol 2007;5:e163.

[13] Bonner-Weir S, Weir GC. New sources of pancreatic beta-cells. Nat Biotechnol 2005;23:857-61

[14] Bonner-Weir S, Baxter LA, Schuppin GT, Smith FE. A second pathway for regeneration of adult exocrine and endocrine pancreas. A possible recapitulation of embryonic development. Diabetes 1993;42:1715-20.

[15] Wang RN, Kloppel G, Bouwens L. Duct- to islet-cell differentiation and islet growth in the pancreas of duct-ligated adult rats. Diabetologia 1995;38:1405-11.

[16] Bonner-Weir S, Taneja M, Weir GC, Tatarkiewicz K, Song KH, Sharma A, et al In vitro cultivation of human islets from expanded ductal tissue. Proc Natl Acad Sci USA 2000;97:7999-8004.

[17] Li M, Miyagawa J, Yamamoto K, Moriwaki M, Imagawa A, Iwahashi H, et al Beta cell neogenesis from ducts and phenotypic conversion of residual islet cells in the adult pancreas of glucose intolerant mice induced by selective alloxan perfusion. Endocr J 2002;49:561-72.

[18] Hayashi KY, Tamaki H, Handa K, Takahashi T, Kakita A, Yamashina S. Differentiation and proliferation of endocrine cells in the regenerating rat pancreas after 90\% pancreatectomy. Arch Histol Cytol 2003;66:163-74.

[19] Xu X, D'Hoker J, Stange G, Bonne S, De Leu N, Xiao X, et al. Beta cells can be generated from endogenous progenitors in injured adult mouse pancreas. Cell 2008;132:197-207.

[20] Inada A, Nienaber C, Katsuta H, Fujitani Y, Levine J, Morita R, et al. Carbonic anhydrase II-positive pancreatic cells are progenitors for both endocrine and exocrine pancreas after birth. Proc Natl Acad Sci USA 2008.

[21] Collombat P, Xu X, Ravassard P, Sosa-Pineda B, Dussaud S, Billestrup N, et al. The ectopic expression of Pax4 in the mouse pancreas converts progenitor cells into alpha and subsequently beta cells. Cell 2009;138:449-62.

[22] Lee JH, Jo J, Hardikar AA, Periwal V, Rane SG. Cdk4 regulates recruitment of quiescent beta-cells and ductal epithelial progenitors to reconstitute beta-cell mass. PLoS One 2010;5:e8653.

[23] Solar M, Cardalda C, Houbracken I, Martin M, Maestro MA, De Medts N, et al. Pancreatic exocrine duct cells give rise to insulin-producing beta cells during embryogenesis but not after birth. Dev Cell 2009;17:849-60.

[24] Kopinke D, Murtaugh LC. Exocrine-to-endocrine differentiation is detectable only prior to birth in the uninjured mouse pancreas. BMC Dev Biol 2010;10:38.

[25] Kushner JA, Weir GC, Bonner-Weir S. Ductal origin hypothesis of pancreatic regeneration under attack. Cell Metab 2010;11:2-3.

[26] Fernandes A, King LC, Guz Y, Stein R, Wright CV, Teitelman G. Differentiation of new insulin-producing cells is induced by injury in adult pancreatic islets. Endocrinology 1997;138:1750-62.

[27] Lechner A, Habener JF. Stem/progenitor cells derived from adult tissues: potential for the treatment of diabetes mellitus. Am J Physiol Endocrinol Metab 2003;284:E259-66.

[28] Liu H, Guz Y, Kedees MH, Winkler J, Teitelman G. Precursor cells in mouse islets generate new beta-cells in vivo during aging and after islet injury. Endocrinology 2010;151:520-8.

[29] Pictet RL, Clark WR, Williams RH, Rutter WJ. An ultrastructural analysis of the developing embryonic pancreas. Dev Biol 1972;29:436-67.

[30] Ackermann AM, Gannon M. Molecular regulation of pancreatic betacell mass development, maintenance, and expansion. J Mol Endocrinol 2007;38:193-206

[31] Murtaugh LC. Pancreas and beta-cell development: from the actual to the possible. Development 2007;134:427-38.

[32] Gittes GK. Developmental biology of the pancreas: a comprehensive review. Dev Biol 2009;326:4-35.

[33] Zaret KS, Grompe M. Generation and regeneration of cells of the liver and pancreas. Science 2008;322:1490-4.

[34] Wandzioch E, Zaret KS. Dynamic signaling network for the specification of embryonic pancreas and liver progenitors. Science 2009;324:1707-10. 
[35] Slack JM. Developmental biology of the pancreas. Development 1995;121:1569-80.

[36] Oliver-Krasinski JM, Stoffers DA. On the origin of the beta cell. Genes Dev 2008;22:1998-2021.

[37] Murtaugh LC, Melton DA. Genes, signals, and lineages in pancreas development. Annu Rev Cell Dev Biol 2003;19:71-89.

[38] Teitelman G. On the origin of pancreatic endocrine cells, proliferation and neoplastic transformation. Tumour Biol 1993;14:167-73.

[39] Herrera PL. Adult insulin- and glucagon-producing cells differentiate from two independent cell lineages. Development 2000;127:2317-22.

[40] Zhou Q, Law AC, Rajagopal J, Anderson WJ, Gray PA, Melton DA. A multipotent progenitor domain guides pancreatic organogenesis. Dev Cell 2007;13:103-14.

[41] Gradwohl G, Dierich A, LeMeur M, Guillemot F. neurogenin3 is required for the development of the four endocrine cell lineages of the pancreas. Proc Natl Acad Sci USA 2000;97:1607-11.

[42] Johansson KA, Dursun U, Jordan N, Gu G, Beermann F, Gradwohl G, et al. Temporal control of neurogenin 3 activity in pancreas progenitors reveals competence windows for the generation of different endocrine cell types. Dev Cell 2007;12:457-65.

[43] Collombat P, Hecksher-Sorensen J, Serup P, Mansouri A. Specifying pancreatic endocrine cell fates. Mech Dev 2006;123:501-12.

[44] Lingohr MK, Buettner R, Rhodes CJ. Pancreatic beta-cell growth and survival - a role in obesity-linked type 2 diabetes? Trends Mol Med 2002;8:375-84.

[45] Dor Y, Brown J, Martinez OI, Melton DA. Adult pancreatic beta-cells are formed by self-duplication rather than stem-cell differentiation. Nature 2004;429:41-6.

[46] Teta M, Rankin MM, Long SY, Stein GM, Kushner JA. Growth and regeneration of adult beta cells does not involve specialized progenitors. Dev Cell 2007; 12:817-26.

[47] Cano DA, Rulifson IC, Heiser PW, Swigart LB, Pelengaris S, German M, et al. Regulated beta-cell regeneration in the adult mouse pancreas. Diabetes 2008;57:958-66

[48] Scaglia L, Cahill CJ, Finegood DT, Bonner-Weir S. Apoptosis participates in the remodeling of the endocrine pancreas in the neonatal rat. Endocrinology 1997; 138:1736-41.

[49] Teta M, Long SY, Wartschow LM, Rankin MM, Kushner JA. Very slow turnover of beta-cells in aged adult mice. Diabetes 2005;54:2557-67.

[50] Krishnamurthy J, Ramsey MR, Ligon KL, Torrice C, Koh A, Bonner-Weir S, et al. p16INK4a induces an age-dependent decline in islet regenerative potential. Nature 2006;443:453-7.

[51] Tanigawa K, Nakamura S, Kawaguchi M, Xu G, Kin S, Tamura K. Effect of aging on B-cell function and replication in rat pancreas after $90 \%$ pancreatectomy. Pancreas 1997; 15:53-9.

[52] Cozar-Castellano I, Fiaschi-Taesch N, Bigatel TA, Takane KK, Garcia-Ocana A, Vasavada R, et al. Molecular control of cell cycle progression in the pancreatic beta-cell. Endocr Rev 2006;27:356-70.

[53] Heit JJ, Karnik SK, Kim SK. Intrinsic regulators of pancreatic beta-cell proliferation. Annu Rev Cell Dev Biol 2006;22:311-38.

[54] Lee YC, Nielsen JH. Regulation of beta cell replication. Mol Cell Endocrinol 2009;297:18-27.

[55] Georgia S, Bhushan A. Beta cell replication is the primary mechanism for maintaining postnatal beta cell mass. J Clin Invest 2004;114:963-8.

[56] Kushner JA, Ciemerych MA, Sicinska E, Wartschow LM, Teta M, Long SY, et al. Cyclins D2 and D1 are essential for postnatal pancreatic beta-cell growth. Mol Cell Biol 2005;25:3752-62.

[57] Rane SG, Dubus P, Mettus RV, Galbreath EJ, Boden G, Reddy EP, et al. Loss of Cdk4 expression causes insulin-deficient diabetes and Cdk4 activation results in beta-islet cell hyperplasia. Nat Genet 1999;22:44-52.

[58] Marzo N, Mora C, Fabregat ME, Martin J, Usac EF, Franco C, et al. Pancreatic islets from cyclin-dependent kinase 4/R24C (Cdk4) knockin mice have significantly increased beta cell mass and are physiologically functional, indicating that Cdk4 is a potential target for pancreatic beta cell mass regeneration in Type 1 diabetes. Diabetologia 2004;47:686-94

[59] Hino S, Yamaoka T, Yamashita Y, Yamada T, Hata J, Itakura M. In vivo proliferation of differentiated pancreatic islet beta cells in transgenic mice expressing mutated cyclin-dependent kinase 4. Diabetologia 2004;47: 1819-30.

[60] Cozar-Castellano I, Takane KK, Bottino R, Balamurugan AN, Stewart AF. Induction of beta-cell proliferation and retinoblastoma protein phosphorylation in rat and human islets using adenovirus-mediated transfer of cyclin-dependent kinase-4 and cyclin D1. Diabetes 2004;53:149-59.

[61] Grouwels G, Cai Y, Hoebeke I, Leuckx G, Heremans Y, Ziebold U, Stangé G, Chintinne M, Ling Z, Pipeleers D, Heimberg H, Van de Casteele M. Ectopic expression of E2F1 stimulates beta-cell proliferation and function. Diabetes 2010;59(6):1435-44.

[62] Krishnamurthy B, Dudek NL, McKenzie MD, Purcell AW, Brooks AG, Gellert S et al. Responses against islet antigens in NOD mice are prevented by tolerance to proinsulin but not IGRP. J Clin Invest 2006;116:3258-65.

[63] Tschen SI, Dhawan S, Gurlo T, Bhushan A. Age-dependent decline in beta-cell proliferation restricts the capacity of beta-cell regeneration in mice. Diabetes 2009;58:1312-20.

[64] Rankin MM, Kushner JA. Adaptive beta-cell proliferation is severely restricted with advanced age. Diabetes 2009;58:1365-72.

[65] Dhawan S, Tschen SI, Bhushan A. Bmi-1 regulates the Ink4a/Arf locus to control pancreatic beta-cell proliferation. Genes Dev 2009;23:906-11.
[66] Chen H, Gu X, Su IH, Bottino R, Contreras JL, Tarakhovsky A, et al. Polycomb protein Ezh2 regulates pancreatic beta-cell Ink4a/Arf expression and regeneration in diabetes mellitus. Genes Dev 2009;23:975-85.

[67] Milne TA, Hughes CM, Lloyd R, Yang Z, Rozenblatt-Rosen O, Dou Y, et al. Menin and MLL cooperatively regulate expression of cyclin-dependent kinase inhibitors. Proc Natl Acad Sci USA 2005;102:749-54.

[68] Karnik SK, Hughes CM, Gu X, Rozenblatt-Rosen O, McLean GW, Xiong Y, et al. Menin regulates pancreatic islet growth by promoting histone methylation and expression of genes encoding p27Kip 1 and p18INK4c. Proc Natl Acad Sci USA 2005;102:14659-64.

[69] DorY, Melton DA. Facultative endocrine progenitor cells in the adult pancreas. Cell 2008;132:183-4.

[70] Guz Y, Nasir I, Teitelman G. Regeneration of pancreatic beta cells from intraislet precursor cells in an experimental model of diabetes. Endocrinology 2001;142:4956-68.

[71] Gelling RW, Du XQ, Dichmann DS, Romer J, Huang H, Cui L, et al. Lower blood glucose, hyperglucagonemia, and pancreatic alpha cell hyperplasia in glucagon receptor knockout mice. Proc Natl Acad Sci USA 2003;100: 1438-43.

[72] Furuta M, Zhou A, Webb G, Carroll R, Ravazzola M, Orci L, et al. Severe defect in proglucagon processing in islet A-cells of prohormone convertase 2 null mice. J Biol Chem 2001;276:27197-202.

[73] Ackermann Misfeldt A, Costa RH, Gannon M. Beta-cell proliferation, but not neogenesis, following $60 \%$ partial pancreatectomy is impaired in the absence of FoxM1. Diabetes 2008;57:3069-77.

[74] Pick A, Clark J, Kubstrup C, Levisetti M, Pugh W, Bonner-Weir S, et al. Role of apoptosis in failure of beta-cell mass compensation for insulin resistance and beta-cell defects in the male Zucker diabetic fatty rat. Diabetes 1998;47:358-64.

[75] Wang ZV, Mu J, Schraw TD, Gautron L, Elmquist JK, Zhang BB, et al. PANICATTAC: a mouse model for inducible and reversible beta-cell ablation. Diabetes 2008;57:2137-48.

[76] Butler AE, Janson J, Soeller WC, Butler PC. Increased beta-cell apoptosis prevents adaptive increase in beta-cell mass in mouse model of type 2 diabetes: evidence for role of islet amyloid formation rather than direct action of amyloid. Diabetes 2003;52:2304-14.

[77] Means AL, Xu Y, Zhao A, Ray KC, Gu G. A CK19(CreERT) knockin mouse line allows for conditional DNA recombination in epithelial cells in multiple endodermal organs. Genesis 2008;46:318-23.

[78] De Haro-Hernandez R, Cabrera-Munoz L, Mendez JD. Regeneration of betacells and neogenesis from small ducts or acinar cells promote recovery of endocrine pancreatic function in alloxan-treated rats. Arch Med Res 2004;35:114-20.

[79] Kodama S, Toyonaga T, Kondo T, Matsumoto K, Tsuruzoe K, Kawashima $\mathrm{J}$, et al. Enhanced expression of PDX-1 and Ngn3 by exendin- 4 during beta cell regeneration in STZ-treated mice. Biochem Biophys Res Commun 2005;327:1170-8.

[80] Heimberg H. Boosting beta-cell numbers. N Engl J Med 2008;359: 2723-4.

[81] Mashima H, Shibata H, Mine T, Kojima I. Formation of insulin-producing cells from pancreatic acinar AR42J cells by hepatocyte growth factor. Endocrinology 1996;137:3969-76.

[82] Mashima H, Ohnishi H, Wakabayashi K, Mine T, Miyagawa J, Hanafusa $\mathrm{T}$, et al. Betacellulin and activin A coordinately convert amylase-secreting pancreatic AR42J cells into insulin-secreting cells. J Clin Invest 1996;97: 1647-54.

[83] Zhou YP, Cockburn BN, Pugh W, Polonsky KS. Basal insulin hypersecretion in insulin-resistant Zucker diabetic and Zucker fatty rats: role of enhanced fuel metabolism. Metabolism 1999;48:857-64.

[84] Lardon J, Huyens N, Rooman I, Bouwens L. Exocrine cell transdifferentiation in dexamethasone-treated rat pancreas. Virchows Arch 2004;444:61-5.

[85] Baeyens L, De Breuck S, Lardon J, Mfopou JK, Rooman I, Bouwens L. In vitro generation of insulin-producing beta cells from adult exocrine pancreatic cells. Diabetologia 2005;48:49-57.

[86] Baeyens L, Bonne S, Bos T, Rooman I, Peleman C, Lahoutte T, et al. Notch signaling as gatekeeper of rat acinar-to-beta-cell conversion in vitro. Gastroenterology 2009;136:e13, 1750-60.

[87] Baeyens L, Bonne S, German MS, Ravassard P, Heimberg H, Bouwens L. Ngn3 expression during postnatal in vitro beta cell neogenesis induced by the JAK/STAT pathway. Cell Death Differ 2006;13:1892-9.

[88] Minami K, Okuno M, Miyawaki K, Okumachi A, Ishizaki K, Oyama K, et al. Lineage tracing and characterization of insulin-secreting cells generated from adult pancreatic acinar cells. Proc Natl Acad Sci USA 2005;102:15116-21.

[89] Means AL, Meszoely IM, Suzuki K, Miyamoto Y, Rustgi AK, Coffey Jr RJ, et al. Pancreatic epithelial plasticity mediated by acinar cell transdifferentiation and generation of nestin-positive intermediates. Development 2005; 132:3767-76

[90] Gu D, Arnush M, Sarvetnick N. Endocrine/exocrine intermediate cells in streptozotocin-treated Ins-IFN-gamma transgenic mice. Pancreas 1997; $15: 246-50$.

[91] Jensen JN, Cameron E, Garay MV, Starkey TW, Gianani R, Jensen J. Recapitulation of elements of embryonic development in adult mouse pancreatic regeneration. Gastroenterology 2005;128:728-41.

[92] Siveke JT, Lubeseder-Martellato C, Lee M, Mazur PK, Nakhai H, Radtke F, et al. Notch signaling is required for exocrine regeneration after acute pancreatitis. Gastroenterology 2008;134:544-55. 
[93] Desai BM, Oliver-Krasinski J, De Leon DD, Farzad C, Hong N, Leach SD, et al. Preexisting pancreatic acinar cells contribute to acinar cell, but not islet beta cell, regeneration. J Clin Invest 2007;117:971-7.

[94] Strobel O, Dor Y, Alsina J, Stirman A, Lauwers G, Trainor A, et al. In vivo lineage tracing defines the role of acinar-to-ductal transdifferentiation in inflammatory ductal metaplasia. Gastroenterology 2007;133:1999-2009.

[95] Zhou Q, Brown J, Kanarek A, Rajagopal J, Melton DA. In vivo reprogramming of adult pancreatic exocrine cells to $\beta$-cells. Nature 2008:7.

[96] Leeson TS, Leeson R. Close association of centroacinar/ductular and insular cells in the rat pancreas. Histol Histopathol 1986;1:33-42.

[97] Pour PM. Pancreatic centroacinar cells. The regulator of both exocrine and endocrine function. Int J Pancreatol 1994;15:51-64.
[98] Gasslander T, Lilja I, Smeds S, Lundquist I, Ihse I. Cholecystokinin is not a major determinant for the changes in beta-cell function seen after pancreaticobiliary diversion in rats. Diabetes Res 1991;18:135-42.

[99] Nagasao J, Yoshioka K, Amasaki H, Mutoh K. Centroacinar and intercalated duct cells as potential precursors of pancreatic endocrine cells in rats treated with streptozotocin. Ann Anat 2003;185:211-6.

[100] Rovira M, Scott SG, Liss AS, Jensen J, Thayer SP, Leach SD. Isolation and characterization of centroacinar/terminal ductal progenitor cells in adult mouse pancreas. Proc Natl Acad Sci USA 2010;107:75-80.

[101] Sangiorgi E, Capecchi MR. Bmi1 lineage tracing identifies a self-renewing pancreatic acinar cell subpopulation capable of maintaining pancreatic organ homeostasis. Proc Natl Acad Sci USA 2009;106:7101-6. 